Artigo Original

\title{
The clinical seminar as a learning methodology: an evaluation of nursing students' views
}

\author{
Seminário clínico como metodologia de aprendiragem: avaliação fundamentada nas opiniões de estudantes \\ de enfermagem
}

Seminario clínico como metodología de aprendizaje: evaluación fundamentada en opiniones de estudiantes de enfermería

José Granero-Molina ${ }^{1}$, Cayetano Fernández-Sola ${ }^{2}$, Adelaida María Castro-Sánchez $^{3}$,
Francisca Rosa Jiménez-López ${ }^{4}$, Gabriel Aguilera-Manrique ${ }^{5}$, Josefa Márquez-Membrive $^{6}$

\begin{abstract}
Objective: To explore students' assessments of the clinical seminar as a complementary teaching method to the clinical practicum experience. Methods: This was a qualitative study based on the hermeneutic phenomenology of Gadamer. Twenty-three open-ended interviews were conducted from among the 132 first-year students who attended an initial clinical practicum. We performed a qualitative analysis of the data using ATLAS.ti software. Results: The students agreed that the clinical seminar gave them the opportunity to learn about procedures, nursing care and interpersonal relationships. They also found it very helpful when they encountered challenging stressful situations as they performed their practice, and believed it allowed them to make a connection between the theory in the classroom and the clinical practice. Conclusions: These seminars can contribute to reducing levels of stress during clinical practice. They can also help students obtain significant learning from their fellows and reduce the theory-practice gap.
\end{abstract}

Keywords: Clinical clerkship; Students, nursing; Problem-based learning

\section{RESUMO}

Objetivo: Avaliar a importância que os alunos atribuem ao seminário clínico como método de ensino complementar às práticas clínicas em estágio. Método: Estudo qualitativo baseado na fenomenologia hermenêutica de Gadamer. Foram realizadas 23 entrevistas abertas entre um universo de 132 alunos do primeiro ano da licenciatura de enfermagem, que assistiram a um seminário clínico, durante o seu primeiro ensino clínico/estágio. Foi realizada uma análise qualitativa dos dados através do software ATLAS.ti. Resultados: Os entrevistados coincidiram na opinião de que o seminário lhes deu oportunidades de aprendizagem sobre procedimentos, cuidados de enfermagem e relações interpessoais. Referiram também que o mesmo foi útil para lidar com situações estressantes e relacionar os conteúdos teóricos com a prática. Conclusões: Este tipo de seminários pode contribuir para a redução dos níveis de estresse durante a prática clínica, para a aquisição e partilha de aprendizagens significativas em grupo e para colmatar lacunas teórico-práticas.

Descritores: Estágio clínico; Estudantes de enfermagem; Aprendizagem baseada em problemas

\section{RESUMEN}

Objetivo: Evaluar la importancia atribuida por los alumnos al seminario clínico como método de enseñanza complementaria a las prácticas clínicas. Método: Estudio cualitativo basado en la fenomenología hermenéutica de Gadamer. Se realizaron 23 entrevistas abiertas entre un universo de 132 alumnos del primer año del pregrado en enfermería, que asistieron a un seminario clínico, durante su primera enseñanza clínica/práctica. Se llevó a cabo un análisis cualitativo de los datos a través del software ATLAS.ti. Resultados: Los entrevistados coincidieron en la opinión de que el seminario les dio oportunidades de aprendizaje sobre procedimientos, cuidados de enfermería y relaciones interpersonlaes. Refirieron también que el mismo fue útil para lidiar con situaciones estresantes y relacionar los contenidos teóricos con la práctica. Conclusiones: Este tipo de seminarios puede contribuir en la reducción de los niveles de estrés durante la práctica clínica, para adquirir y compartir aprendizajes significativos en grupo y para corregir lagunas teórico-prácticas.

Descriptores: Prácticas clínicas; Estudiantes de enfermería; Aprendizaje basado en problemas

\footnotetext{
${ }^{1}$ PhD. Professor of the Faculty of Health Science, University of Almeria.

${ }^{2}$ PhD. Professor of the Faculty of Health Science, University of Almeria.

${ }^{3}$ PhD. Professor of the Faculty of Health Science, University of Almeria.

${ }^{4}$ PhD. Professor of the Faculty of Health Science, University of Almeria.

${ }^{5}$ PhD. Head of the Nursing and Physiotherapy Department, University of Almeria.

${ }^{6}$ Bachelor of Science Nursing. Commissioner of the Degree. University of Almeria.
} 


\section{INTRODUCTION}

The importance of initial clinical education on learning in the health professions cannot be questioned ${ }^{(1-2)}$, primarily because an ever increasing number of educational theorists began emphasizing the social and cultural nature of knowledge, and, in particular, the role played by practice and experience on the development of skills ${ }^{(3)}$. However, it should be approached as a period during which it is vital for the faculty to provide attention ${ }^{(4-6)}$. Considering this, development and evaluation of clinical learning strategies are needed to enable efficiency and optimization of the limited clinical centers ${ }^{(7)}$. Research on the experiences and perceptions of nursing students during their clinical placement has been conducted during the last few decades. Generally, studies have shown that students experience stress and anxiety ${ }^{(5,8)}$, a feeling of abandonment and incompetence ${ }^{(9)}$, a clash with reality or the theory-practice gap ${ }^{(10)}$, shame and humiliation ${ }^{(11)}$, a sense of impermanence and generational tensions which prevent them from integrating into a team ${ }^{(6)}$, leading to feelings of invisibility or of being ignored ${ }^{(12)}$ or discriminated against ${ }^{(13)}$. Sometimes, students believe they are supposed to function as qualified members of the clinical team ${ }^{(14-15)}$.

\section{Background}

There have been various strategies described for minimizing these problems and optimizing the period of clinical practice training. Among these strategies, the Dedicated Education Unit (DEU) ${ }^{(16-17)}$ is relevant, and is defined as "a client unit that is developed into an optimal teaching/learning environment through the collaborative efforts of nurses, management, and faculty" ${ }^{(17)}$. One study ${ }^{(8)}$ identified different measures available to reduce anxiety within the clinical training environment, such as the use of humor, collective instruction or tutorials together with Mindfulness-Based Stress Reduction programs. Another author proposed a better understanding of the components in clinical education from the student's point of view ${ }^{(4)}$. Other authors developed a cooperative learning model where advanced students supervise beginners ${ }^{(18-20)}$.

Concerned with the stressful effect of the first clinical placement, and the integration of theory and practice for nursing students in the Faculty of Health Science (FHS) in the University of Almeria (UAL), the teaching staff for the first year designed and implemented the Clinical Seminar (CS). The CS is developed within the framework of a pilot experience, aimed at implementing the European Higher Education Area. ${ }^{(21-22)} \mathrm{It}$ is based on different strategies, developed to reduce stress during training, increase students' performance, and to integrate theory and practice. Some of these were instituted during periodical meetings held with clinical placement students, called supervision programs ${ }^{(1,23)}$ or clinical seminars $^{(24)}$.

Emotional support and clinical management increase performance and improve patient care ${ }^{(2)}$. The first session of the CS was held weekly during the hospital clinical placement. This first session consisted of two hour meetings for groups of 10-12 students, in the same work centre where they were being trained. In this first session, the teacher explained the main goals of the CS and each student explained: the characteristics of the unit or service to which they were assigned; experiences and subsequent emotions; difficulties arising from the performance of different procedures: and, their perception of the similarities and differences between the way basic procedures were conducted in hospital and the way they were taught in the classroom or during laboratory simulation.

The integration of theory and practical training is necessary to help nursing students apply theoretical knowledge in practical situations ${ }^{(22,26)}$. The second session of the CS was held during the last week of the hospital clinical placement. It included a general assessment of the clinical practicum and a study of cases in which professional practice was related to the theoretical aspects of the subject. In order to do this, each student group (two students) produced an initial assessment for a patient of its choice, formulating nursing diagnoses, and described the nursing care plan. In this phase, the debate focused on analyzing the congruency of the care plan using the theoretical assumptions of Virginia Henderson's model.

In response to the need to assess the instruments and methods applied in the learning-teaching process, this study was designed to explore the opinions of the first year nursing students following the introduction of the CS. The research questions for the study were: How valuable do students regard the CS, as a complementary method to the clinical practicum training? What benefits were obtained through their participation in the CS? During the CS sessions, what did they learn, and how?

\section{METHODS}

This was a phenomenological study based on Gadamer's hermeneutic philosophy, performed between the years 2008 to 2009, at the FSH in the UAL. Phenomenology is based on existentialism; phenomenology, hermeneutics, and existentialism are natural fellows, since in pointing to the experential world, phenomenology grounds our research inquiries, focusing us on the concrete happenings of the lived experience, to understand the meaning behind our reflections ${ }^{(27)}$. Gadamer is a German philosopher influenced by the work of Husserl and 
Heidegger. However, he rejects the notion of phenomenological reduction and claims that all understanding arises only in and through our pre-understanding of the world, which exists by our very nature of being in the world $^{(28)}$. In this case, we, as researchers, exist within the world as nurse educators; we have been students and clinical nurses. We designed the study to ascertain if the CS addressed problems that arise during clinical placements. We already had an understanding of these problems due to our position as former students, nurses and educators. Regarding the collection of data, we sought information relating to the students' perceptions of the impact of the CS on resolution of said problems. In the presentation and interpretation of the results, we used these "problems" as predefined categories that, together with the emerging categories, comprised the category tree of our study.

For this study, the population consisted of 132 firstyear nursing students in the FSH at the UAL. A total of 23 students, ranging in age from 18 to 25 years old, with an average age of 19.1 years old, were chosen using theoretic sampling. Of these, 18 were women and 5 were men. The inclusion criterion was that the students had participated in the two CS sessions. The number of participants was not determined beforehand, but was fixed when theoretical saturation occurred.

Data Collection: The open-ended interviews were conducted by researchers during the two days which followed the two CS sessions. In order to avoid skewed responses, students were reminded that the interviewers were not their professors. To allow for the interviews to be transcribed, they were recorded using .mp4 format. After each interview, the interviewers immediately made field notes which were also analyzed.

A question guide was available for the first interviews, with the general open-ended question, "You have just finished participating in a seminar with your professors, could you evaluate your experience?” Afterwards, if the reply had not covered the points required by the researcher, probing questions were asked to gain more information such as, "What have you learned in the CS?”; "The characteristics of the CS are...". After the analysis of the first interviews began, new questions were included to gather information in emerging categories which had not been sufficiently developed such as, "What role do your colleagues have in the CS?".

Data Analysis: The qualitative analysis began with transcribing and reading the interviews during the period in which data collection was also occurrring. Afterwards, a content analysis was conducted using constant comparative techniques to evaluate the variation or similarity among data collected. ATLAS.ti $5.2 \AA$ software was employed for the analysis. Analysis was a circular or cyclical process, in which three levels for interpret- ing data were used: syntactic level analysis, identifying the most relevant answer fragments as quotations, and, assigning a code to each quotation. A semantic level of data interpretation occurred through the creation of code families and free codes, gathering codes into "Categories", which constituted phenomena especially relevant to the research question ${ }^{(29)}$. The pragmatic level of data interpretation, in which a network among quotations, codes and/or code families was established, was conducted to provide graphic representations of these interactions

Once the 23 interviews were analyzed, and when there were no new elements appearing in the analysis, the authors determined that the stage of theoretical data saturation had been reached, and that the information gathered was sufficient for the aims set.

To avoid researcher bias and to increase the validity of this study, we invited two independent colleagues to analyze the categories, subjecting them to discussion, and to provide us with a final listing. Thereafter, we immediately performed a re-reading of the transcriptions to confirm that the categories chosen covered all of the aspects needed.

The study was approved by the Nursing and Physiotherapy Department of the University of Almeria. The free and informed consent was obtained before the interviews took place. Confidentiality and anonymity were ensured, as well as the possibility of refusing to participate or answer the questions.

\section{RESULTS}

The qualitative data were organized according to four main categories that were derived from the analysis. Quotations were identified with the number of the interview and the paragraph of the transcription. For instance, QU12:17 means that the quotation can be found in interview 12, paragraph 17. Figures are accompanied by a reading key.

\section{Characterization of the CS: a positive experience}

Students showed a remarkably positive attitude towards the implementation of the CS, related to their characterization of the CS; this positive response was present in 20 out of the 23 interviews, as seen in Figure 1. The health sciences exist within a world where absolute certainties are scarce, and where experts' judgments are not always sufficient. This is why we have to go beyond what is established in textbooks or teachers' lessons and use other knowledge resources derived from praxis and the lived world. The students saw their participation in the CS as an efficient, entertaining and useful way to acquire significant knowledge. 


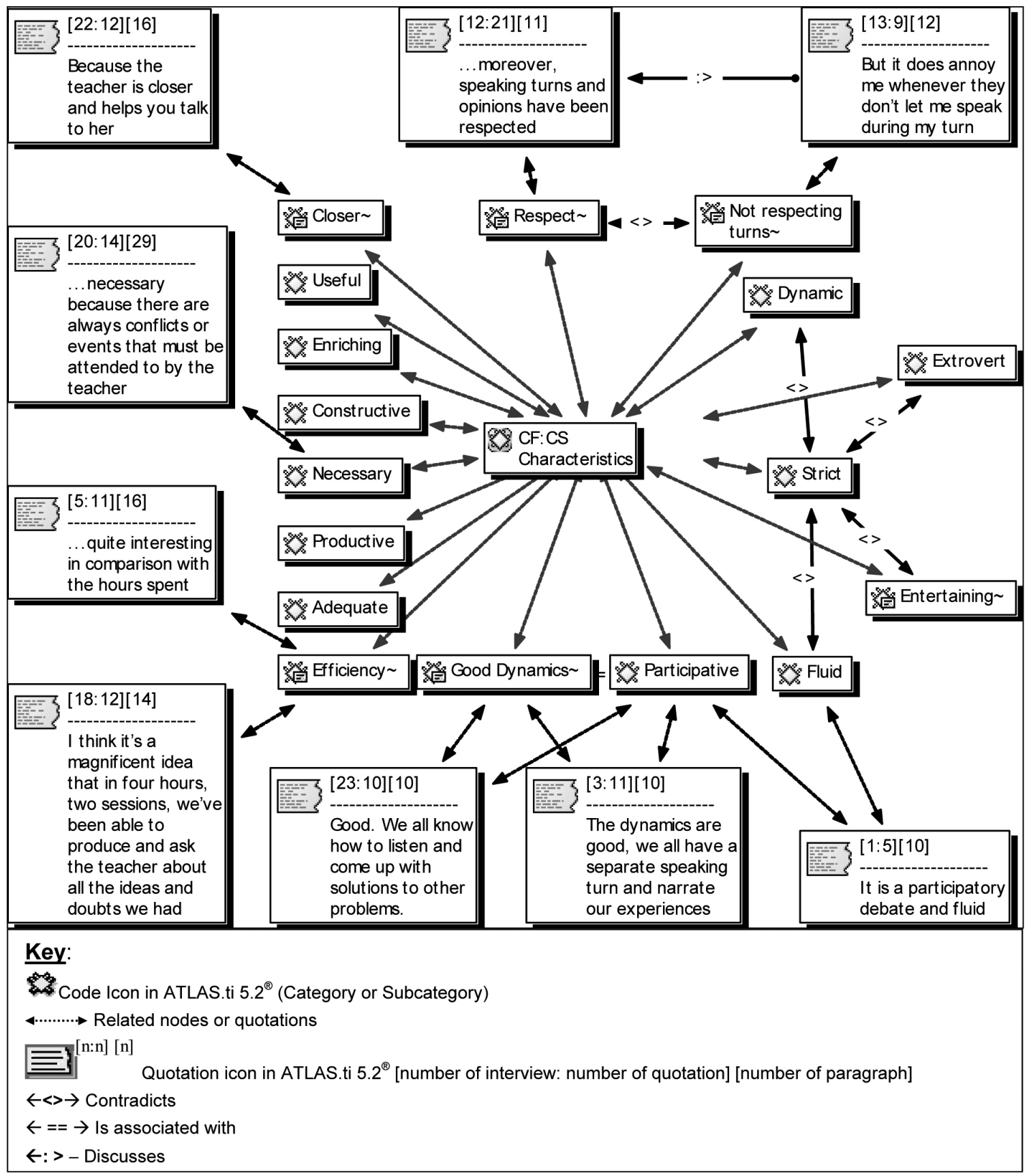

Figure 1. Characterization of the CS.

\section{Peer learning led by professor}

The most quoted element was "Classmates" who, through their different experiences and dialogue, constituted a main source for learning and collective support in the CS. The next nuclear element within the CS was the "Professor", who was considered to be someone who was close, who guided and facilitated learning, becoming an element of "help", support and understanding within a stressful environment. Subsequently, from the conjunction of these two actors ("Classmates" and "Professor"), students obtain "Learning", which can be related to: the best way to perform nursing care and procedures: "since each of us is on a different ward, patients suffer from different diseases and we share the procedures" (QU4:6); the way to cope with new situations: "T've learned how to react in an unpleasant situation"(QU15:4); hospital work: "We're introduced to working in hospitals and to different wards in which we haven't worked yet" (QU19:10); performing their professional role: "one of the most important things I've learned is to critically identify one who is a good professional and one who isn't" (QU12:14); and, interpersonal relationships: "The reinforcement of my idea 
regarding how to treat people has been the most important thing for me. I stick to that. The better you treat them, the better they feel" (QU12:4). These interpersonal relationship include relationship with patients: "I have learned ideas produced about classmates about how relationships within the team and with patients work." (QU7:4), and with professionals, "I have learned how to react in the face of staff rejection" (QU19:4).

The way in which this learning process occurs was also documented. Classmates' "Experiences" were one of the most relevant elements: "We share all our experiences in the debate (...) and so, we learn from what happens to others" (QU11:7); as well as ideas, knowledge and information provided by students and professor, to be compared, exchanged, cleared or reinforced: "These seminars have reinforced many of the ideas I'd been tanght but haven't used yet, they have also helped me to assess my patients" (QU23:4). Finally, students learned from the mistakes they made or observed during their placement: "I've learned a lot and I have been able to realize my mistakes and why they were mistakes" (QU23:13). This main role played by the students reinforced a cooperative learning in which the professor could assume new roles as a leader and helper in the learning-teaching process versus the traditional lecturer, where students were passive receivers of the information delivered by the professor.

\section{Stress reduction CS}

The stress reducing traits of the CS were based on the perception students had that sharing their negative experiences relieved and consoled them: "T believe knowing the problems of others helps us coping with ours better" (QU19:20). The CS offered students the opportunity to complain about what they did not like, which contributed to the reduction of stress through their peers' and professor's support, and reinforced the idea that the CS strengthened the ties that bound them. "I've found very sound psychological support here, most of all in the first session, where every student is strongly encouraged" (QU6:9). This was particularly relevant in the initial clinical placement which constituted an important source of stress, along with several negative feelings for the student (e.g., anxiety, embarrassment or humiliation). Although stress can be an incentive for adaptation, it can also have a negative influence on the learning process and students' performance when the levels are high.

\section{Theory-Practice Gap}

If professors tend to provide positivist explanations where technological views are highlighted, the nursing theories and patterns will be enclosed within an academic environment which overwhelms the students, due to the amount of concepts they cannot apply, thereby widening the theory-practice gap. Some students prioritized the clinical learning framework over theory lessons: "hospital work has taught me more than all I learnt in theory class"(QU13:16). Yet, they also stated that the right way to execute certain procedures can not always be seen in hospitals. "Talking to my classmates and professor has helped me to see that, very often, nurses don't act as they should and neglect their work" (QU22:4). All this refers to the gap between theory and practice, more clearly defined in interview 21 with a question that refers to the core of the problem: "There is a buge difference between working with 'toys' [simulators] and with people, and between the procedures of one professional and another one [nursing procedures and cares]" (QU 21:20). Simulation in labs with mannequins and other simulators contributed to psychomotor skills and manual dexterity, but when the student was confronted with real people $\mathrm{s} /$ he perceived a great difference. Another element identified by many students, was the variation in care and performing procedures. They found it very disturbing to learn that the theory of procedures is taught one way in the classroom, and implemented in a very different way in hospitals. Almost all of them believed that the CS was the appropriate place to deal with that variation, being able to tell right from wrong, learning from this initially disturbing element: "It is important for us to learn how to change what we've seen done in an inappropriate way, so as to avoid making mistakes" (QU11:16). Some other students in the CS found what they were taught in class about the importance of treating the patient correctly was fundamental: "During these seminars, I've realized it is important to treat patients and their relatives beyond technique. At first I thought that was silly, but now I see it is essential" (QU12:8). This is why the efficiency and usefulness of the dialogue and reflection on the experiences obtained while in a clinical placement, guided by faculty who move to clinical environments, was found in the integration of theory and practice, providing maximum learning of the lived experiences in the actual clinical framework: "[the CS] teaches us more than a theory lesson since it's about things we've witnessed or experienced ourselves"(QU18:4). Nursing science is mainly practical, with its final aim being to intervene in the world in order to change it rather than to explain, predict and control events of reality. One of the mechanisms by which professional knowledge is generated and produced is the reflection on actions. In other words, the reflective-practical rationality can be more useful that the technical in the practice and learning of care.

\section{DISCUSSION}

We emphasized in our study the importance that students attribute to the possibility of exchanging ideas and experiences among themselves and with the faculty professor. Various studies have highlighted the importance of giving students the opportunity to think over and verbalize their feelings about their first clinical ex- 
periences $^{(9,25)}$. Sharing their experiences with classmates and professors in a structured way offers very necessary support since, while participating in these sessions, students realize they are not the only ones having those feelings ${ }^{(9)}$. The CS provided students with the opportunity to reflect on their professional activity, obtaining a critical view of interpersonal relationships between patients, relatives and professionals. These relationships must also be considered by the faculty as another element of the nursing students' curriculum ${ }^{(30)}$. The teacher can assume the role of mediator ${ }^{(13)}$, showing the importance of the clinical nurse in the students' training ${ }^{(30)}$. The experience gained during the clinical placements and the network of relationships established within it contributes to the graduate's later incorporation into the work team ${ }^{(31)}$.

The Critical Incident Technique framework ${ }^{(24)}$ allows the student to examine a situation comprehensively arising during the seminar as participants discuss issues based on the experiences of students. In the first sessions of these weekly seminars using this framework, a certain source for collective support is provided, and the following sessions evolve toward an analysis of cases, as occurred during our study. The role of the professor varies as well, from being a supportive element in the first session to becoming the facilitator of dialogue about those analyzed cases. Likewise, it has been stated that the seminar increases trust within the group, which supported our assumption, that the CS "strengthened ties" among students and professors ${ }^{(24)}$. Our assumptions were also supported by another study, in which there was a warning about one of the most stressful experiences: the initial clinical practicum. These authors also believed the peer learning system encouraged students' clinical performances, relieved anxiety and developed collegiality among students as they took time to support and listen to one another ${ }^{(18)}$.

Students in our study, in agreement with other research $^{(10,26)}$, highlighted the discrepancy between the theoretical studies and the practical learning in the clinical area. The difficulty of transfering knowledge from one situation to another, ${ }^{(32)}$ and the reality of university professors being more and more removed from the clinical practice, ${ }^{(25)}$ have both been highlighted as causes of this theory-practice gap. Moreover, those who defend the supremacy of the social environment, also forget that the reciprocal relationship between theory and practice is vital for professional training.

A recent study reported, "It is during this reflective time that students make linkages from theory in class to the reality of a working unit"(33). Some of our students obtained a unique learning experience based on this duality, which they initially perceived as disturbing. Therefore, the CS integrated theory and practice because, through dialogue, students reviewed their behaviors critically, making a distinction between what was right and what was wrong according to what they studied in the theory lessons. This prevented the appearance of such a phenomenon as that described ${ }^{(10)}$, which consists of the belief that, when confronting a gap between theory and practice, the student will tend to discard the credibility of the professor, rather than making a critical analysis of what $\mathrm{s} /$ he observed in practice.

Students who participated in a study on a clinical placement supervision program with weekly sessions claimed that it helped them integrate theory and practice and positively influenced the quality of their patient care $^{(23)}$. Students in DEU had a more positive attitude than those in the traditional practice group about most aspects of clinical practice, and they had a better understanding of the synergy between theory and practice ${ }^{(15)}$. Some dimensions of the peer learning process ${ }^{(20)}$ appeared in our study, since it was perceived to be a satisfactory experience by students, who experienced learning facilitation and emotional support from their classmates. This positive assessment of the CS focused on the fact that first year students noticed improvements in their cognitive and motor skills, increased confidence in their capacity to ask questions and discuss concerns, and a deeper understanding of the functions each member of the health team performed ${ }^{(19)}$.

In terms of the limitations of the study, results cannot be extrapolated to a wider group due to the fact that the study was based in a qualitative methodology. A triangulation with different data sources could have improved the generalizability of the results. The locale and small scale of the study was chosen because it was developed within the framework of an examination of innovative teaching experiences limited to one university. Only first year students (doing their initial clinical placements) were interviewed; including more advanced students from other years may have shown different results.

\section{CONCLUSIONS AND IMPLICATIONS}

In the CS, students learned from each other's experiences, guided by the professor, and obtained help and emotional support to face stressful situations. The CS was perceived to be an effective method to complement their clinical practice training, according to the students. They obtained not only academic benefits, such as the development of competencies and the capacity to apply theories, but also personally learned the value of interpersonal relationships in life and work. During this learning, peers became especially relevant, together with experiences with the professor, as both leaders and helpers in this process. Taking this into consideration, the new study plan for our faculty, designed for adapting nursing studies to the European Higher Education Area, includes clinical seminars as part of the dedicated Practicum teaching time. 


\section{REFERENCES}

1. Saarikoski M, Leino-Kilpi H, Warne T. Clinical learning environment and supervision: testing a research instrument in an international comparative study. Nurse Educ Today. 2002; 22(4): 340-9.

2. Ernstzen DV, Bitzer E, Grimmer-Somers K. Physiotherapy students' and clinical teachers' perceptions of clinical learning opportunities: a case study. Med Teach. 2009;31(3):e102-15.

3. Field DE. Moving from novice to expert - the value of learning in clinical practice: a literature review. Nurse Educ Today. 2004; 24(7): 560-5.

4. Chan DS. Nursing students' perceptions of hospital learning environments- an Australian perspective. Int J Nurs Educ Scholarsh [Internet]. 2004 [citado 2009 Ago 5]; 1(1), [15 p.]. Disponível em: http:/www.bepress.com/ijnes/vol1/iss1/art4.

5. Basso Musso L, Ardiles Vargas B, Bernal Torres M, Canovas Del Canto MJ, González Meléndez C, Kroff Balloqui MF, et al. Factors derived from the intrahospitable laboratories that cause stress in infirmary students. Rev Latinoam Enferm. 2008; 16(5): 805-11.

6. Newton JM, Billett S, Ockerby CM. Journeying through clinical placements - An examination of six student cases. Nurse Educ Today. 2009; 29(6): 630-4.

7. Murray TA, Crain C, Meyer GA, McDonough ME, Schweiss DM. Building bridges: An innovative academic-service partnership. Nurs Outlook. 2010; 58(5): 252-60.

8. Moscaritolo LM. Interventional strategies to decrease nursing student anxiety in the clinical learning environment. J Nurs Educ. 2009; 48(1): 17-23.

9. Beck CT. Nursing students' initial clinical experience: a phenomenological study. Int J Nurs Stud. 1993; 30(6): 489-97.

10. Corlett J. The perceptions of nurse teachers, student nurses and preceptors of the theory-practice gap in nurse education. Nurse Educ Today. 2000; 20(6): 499-505.

11. Bond ME. Exposing shame and its effect on clinical nursing education. J Nurs Educ. 2009; 48(3): 132-40.

12. Curtis J, Bowen I, Read A. You have no credibility: nursing students' experiences of horizontal violence. Nurse Educ Pract. 2007; 7(3): 156-63.

13. Vera I, Aversi-Ferreira TA, Lucchese RA. The experience of a faculty mentor to indigenous nursing students. Acta Paul Enferm. 2011; 24(2): 289-93.

14. Costa MLAS, Merighi MAB, Jesus MCP. Being a nurse after having been a nursing student-worker: an approach of social phenomenology. Acta Paul Enferm. 2008; 21(1): 17-23

15. Edgecombe K, Bowden M. The ongoing search for best practice clinical teaching and learning: A model of nursing students' evolution to proficient novice registered nurses. Nurse Educ Pract. 2009;9(2): 91-101.

16. Edgecombe K, Wotton K, Gonda J, Mason P. Dedicated education units 1: A new concept for clinical teaching and learning. Contemp Nurse. 1999; 8(4): 166-71.

17. Moscato SR, Miller J, Logsdon K, Weinberg S, Chorpenning L. Dedicated Education Unit: an innovative clinical partner education model. Nurs Outlook. 2007; 55(1): 31-7.

18. Becker MK, Neuwirth JM. Teaching strategy to maximize experience with beginning nursing students. J Nurs Educ. 2002; 41(2), 89-91.

19. Daley LK, Menke E, Kirkpatrick B, Sheets D. Partners in Practice: a win-win model for clinical education. J Nurs Educ. 2008; 47(1): 30-2.

20. Li HC, Wang LS, Lin YH, Lee I. The effect of a peermentoring strategy on student nurse stress reduction in clinical practice. Int Nurs Rev. 2010; 58(2): 203-10.

21. Díaz-González CM, García-Álvarez D, Bordón-Medina CD, Lobato-Santana AL, Suárez-García MP. Nursing in the Canary Islands and the academic and professional changes. Enferm Clin. 2010; 20(4): 243-9.

22. Granero-Molina J. Fernández-Sola C, Castro-Sánchez A, Aguilera-Manrique G. Aprendizaje basado en problemas: seminario integrado en el grado de enfermería. Form Univ [Internet]. 2011 [cited 2012 Feb 12];4(4): 29-36. Available from: http://www.scielo.cl/pdf/formuniv/v4n4/art05.pdf

23. Severinsson EI. Bridging the gap between theory and practice: a supervision program for nursing students. J Adv Nurs. 1998; 27(6): 1269-77.

24. Owen S, Wheway J, Anderson M. The use of a journal club and clinical seminars on a 4-year undergraduate, preregistration mental-health nursing degree. Nurse Educ Today. 2001: 21(4): 297-303.

25. Smith P, Allan TH. We should be able to bear our patients in our teaching in some way": theoretical perspectives on how nurse teachers manage their emotions to negotiate the split between education and caring practice. Nurs Educ Today. 2010; 30(3): 218-23.

26. Scherer ZA, Scherer EA. Reflections on nursing teaching in the post-modernity era and the metaphor of a theory-practice gap. Rev Latinoam Enferm. 2007; 15(3): 498-501.

27. Todres L, Wheeler S. The complementarily of phenomenology, hermeneutics and existentialism as a philosophical perspective for nursing research. Int J Nurs Stud. 2001; 38(1): 1-8.

28. Gadamer HG. Verdad y método. Vol II. Salamanca: Sígueme; 2005.

29. Strauss AL, Corbin J. Basics of qualitative research. London: SAGE; 1990.

30. dos Santos MF, Merighi MA, Muñoz LA. The experience of clinical nurses with nursing students: a phenomenological analysis. Rev Esc Enferm USP. 2009; 43(3): 528-33.

31. Mattosinho MM, Coelho MS, Meirelles BH, de Souza SS, Argenta CE. [The world of work: some aspects experienced by professional nurses recently graduated]. Acta Paul Enferm. 2010; 23(4): 466-71. Portuguese.

32. Lauder W, Sharkey S, Booth S. A case study of transfer of learning in a family health nursing course for students in remote and rural areas. Nurse Educ Pract. 2004; 4(1): 39-44.

33. Powell RM. Improving students' delegation skills. Nurs Educ. 2011; 36(1): 9-10. 